\title{
Polonica in the Swedish National Archives. The Skokloster Collection and Other Materials, ed. by A. Nowicka-Jeżowa, E. Teodorowicz-Hellman, Stockholm 2007, ss. 174.
}

W ostatnich latach daje się zauważyć duże zainteresowanie wśród polskich badaczy, wywiezionymi przez Szwedów z ziem Rzeczypospolitej, rękopisami i drukami z XVI i XVII w. Do Szwecji trafiły one w trakcie wojen polsko-szwedzkich w XVII w. i stanowią one nierzadko również kolekcje całych wywiezionych bibliotek. Celem tego działania nie była jedynie polityka rabunkowa, lecz również przekonanie wśród Szwedów, że zagrabione materiały przyczyniają się do wzbogacenia kultury szwedzkiej i pogłębienia wiedzy na temat podbijanego kraju. Działania te były swego rodzaju „modą” na gromadzenie kolekcji rękopiśmiennych czy książkowych. Już Gustaw Adolf nakazał swoim wojskom, by w łupach dla króla znalazły się także księgozbiory ${ }^{1}$. Zresztą zainteresowanie księgozbiorami z obcych państw nie ograniczało się tylko do Rzeczypospolitej, bowiem w trakcie wojny trzydziestoletniej Szwedzi rabowali wszystkie napotkane biblioteki europejskie, które później dzieliła królowa Krystyna pomiędzy Bibliotekę Królewską, bibliotekę w Uppsali oraz inne pomniejsze ${ }^{2}$. Chociaż pokój oliwski z 1660 r. nakazywał zwrot zagrabionych zbiorów Rzeczypospolitej, to znaczna część polskich dokumentów i książek nadal pozostawała w rękach Szwedów3. Duża część polskich archiwaliów i starodruków spaliła się podczas wielkiego pożaru w Sztokholmie w 1697 r. Spora część polskich materiałów znalazła się w prywatnych kolekcjach, które z czasem przeszły na własność Archiwum Państwowego w Sztokholmie, m.in. znany zbiór gen. Wrangla.

Polskie misje badawcze w Sztokholmie najpierw miały charakter rewindykacyjny, starano się odzyskać przynajmniej część zbiorów. Największym sukcesem było odkupienie części polskich materiałów przez ks. Adama Czartoryskiego, który przybył do Szwecji w 1810 r. Materiały te zostały oddane Bibliotece Czartoryskich w Puławach. Po 1830 r. Szwedzi już nie oddali Polakom żadnych materiałów ${ }^{4}$. Właśnie dlatego od tej pory polskie misje badawcze były wyłącznie o charakterze kwerend i badawczym. W 1844 r. do Szwecji przybył historyk - hrabia Eustachy Tyszkiewicz ${ }^{5}$, w 1896 r. historyk - prof. Aleksander Hirsch-

\footnotetext{
1 Sprawozdanie z poszukiwań w Szwecyi dokonanych z ramienia Akademii Umiejętności przez E. Barwińskiego, L. Birkenmajera, J. Łosia, red. E. Barwiński, Kraków 1914, s. VI-VIII.

2 E. Teodorowicz-Hellman, Z historii $i$ wspótczesności zbioru Skoklostersamlingen, [w:] Polonika Archiwum Narodowego Szwecji. Skoklostersamlingen, t. 1, red. A. Nowicka-Jeżowa, Warszawa 2006, s. 18

3 L. Weibull, Om de under Karl X Gustafs krig till Sverige förda polska arkiven, b.m. 1901.

4 E. Teodorowicz-Hellman, Z historii..., s. 20.

5 Po powrocie opublikował książkę: E. Tyszkiewicz, Listy o Szwecji z rycinami, Wilno 1846.
} 
berg ${ }^{6}$. W 1911 r. Akademia Umiejętności wysłała polską misję celem zbadania zasobów szwedzkich archiwów w zakresie polskich archiwaliów. W skład misji wchodzili: dyrektor Archiwum Państwowego we Lwowie Eugeniusz Barwiński, Ludwik Birkenmajer i prof. Jan Łoś z Uniwersytetu Jagiellońskiego. Efektem sześciotygodniowych badań i kwerend była publikacja Sprawozdanie z poszukiwań w Szwecji dokonanych z ramienia Akademii Umiejętności przez E. Barwińskiego, L. Birkenmajera, J. Łosia ${ }^{7}$. Jednakże, jak zauważył Franciszek Olipra, misja Akademii Umiejętności swoje zadanie ograniczyła jedynie do materiałów wywiezionych przez Szwedów, natomiast nie interesowały polskich uczonych materiały dotyczące Rzeczpospolitej, a dotyczące m.in. stosunków dyplomatycznych polsko-szwedzkich czy stosunków rosyjsko-polskich (materiały te zagrabione zostały Rosjanom przez) $)^{8}$. W 300 rocznicę potopu szwedzkiego w 1955 r. dzięki staraniom prof.prof. Antoniego Mączaka i Mariana Małowista został częściowo zmikrofilmowany bardzo cenny zbiór zwany Extranea IX. Polen. Mikrofilmy z tego zespołu zostały przekazane Archiwum Głównemu Akt Dawnych w Warszawie. Wyniki swoich kwerend przedstawił A. Mączak w artykule Wyniki poszukiwań źródłowych dotyczacych wojny polsko-szwedzkiej 1655-16609.

W ostatnich zaś latach dzięki Fundacji na Rzecz Nauki Polskiej oraz Kungliga Vittterhets Historie och Antikvitets Akademien i Wennergrens Centrum został stworzony zespół naukowy do opracowania zbioru Skoklostersamlingen. Ze strony polskiej głównym reprezentantem tego zespołu jest prof. Alina Nowicka-Jeżowa z Zakładu Literatury i Kultury Epok Dawnych w Instytucie Literatury Polskiej Uniwersytetu Warszawskiego, ze strony szwedzkiej prof. Ewa Teodorowicz-Hellman z Instytutu Języków i Literatur Słowiańskich Uniwersytetu Sztokholmskiego.

Recenzowana pozycja Polonika w Archiwum Narodowym Szwecji. Kolekcja Skokloster $i$ inne zbiory wydana przez Stockholms Universitet i Slaviska Institutionen jest pozycją pokonferencyjną. Znajdują się w niej referaty wygłoszone na międzynarodowej konferencji, która odbyła się w dniach 8-10 maja 2006 r. w Instytucie Języków i Literatur Słowiańskich Uniwersytetu Sztokholmskiego. Konferencja była poświęcona pamięci prof. Józefa Trypućki, wybitnego językoznawcy i slawisty związanego z Uniwersytetem w Uppsali, badacza polskiego

6 Wynikiem jego kwerend jest książka: A. Hirschberg, Z wycieczki naukowej do Szweyi, Lwów 1896.

7 Sprawozdanie z poszukiwań w Szwecji dokonanych z ramienia Akademii Umiejętności przez E. Barwińskiego, L. Birkenmajera, J. Łosia, red. E. Barwiński, Kraków 1914.

8 F. Olipra, Polonika w Szwecji (Przyczynek do nowszych polskich badań historycznych), [w:] Adam Mickiewicz. Księga pamiq̨tkowa na stulecie zgonu Adama Mickieiwcza, Stockholm 1955, s. 75-87.

9 A. Mączak, Wyniki poszukiwań źródtowych dotyczących wojny polsko-szwedzkiej 1655-1660, PH 47 (1956), s. 126-142. 
języka literackiego w XIX w. W książce znajdują się również teksty podsumowujące wspomniany wyżej projekt badawczy szwedzko-polski. Autorzy skupiali się głównie na polonikach należących do zbioru Skoklostersamlingen. Polska brev och handlingar, znajdujący się w Riksarkivet w Sztokholmie, ale również prezentowali teksty dotyczące innych zespołów, gdzie znajdują się polskie archiwalia.

Książka jest napisana w dwóch językach: polskim i angielskim. Teksty polskie zawierają streszczenie $\mathrm{w}$ języku angielskim, natomiast teksty angielskojęzyczne streszczenia w języku polskim, co jest bardzo przydatne. Całość otwiera wstęp napisany przez prof.prof. Alinę Nowicką-Jeżową i Ewę Teodorowicz-Hellman, w którym wyjaśniony zostaje cel powstania tej książki. Cennym tekstem jest Polonica in the Swedish National Archives - Riksarkivet. The Skokloster Collection autorstwa prof. E. Teodorowicz-Hellman, która przytoczyła czytelnikom historię zbioru, opisuje kolekcję oraz przedstawia najnowsze wyniki badań nad tym zagadnieniem. Kolejny tekst prof. A. Nowickiej-Jeżowej Polonica in the Skoklostersamlingen Holdings. A Research Reconnaissance przybliża nam siedemnastowieczne teksty $\mathrm{z}$ tego zbioru wydane już w 2006 r. ${ }^{10}$ Kolejny tekst autorstwa Marty Kacprzak Sprawa Smoleńska. Z literatury okolicznościowej polskiego baroku w zbiorach Archiwum Narodowego Szwecji, który streszcza uwagi zawarte w opublikowanej pozycji Sprawa Smoleńska. Dariusz Chemperek zastanawia się w swoim tekście: Kultura literacka początków XVII wieku świetle poetyckich poloników szwedzkich wydanych w XXI wieku nad wartością dla badaczy literatury trzech wydanych drukiem tekstów źródłowych: „,Reges et principes Regni Poloniae" Adriana Kochana Wolskiego jako przyktad wierszowanego katalogu władców $w^{11}$, wspomniany wyżej tom Sprawa Smoleńska, oraz również wspomniany tom Pamiątka rycerstwa sarmackiego. Michał Straszewicz natomiast przedstawił tekst Stan i perspektywy edycji poloników o tematyce moskiewskiej ze zbiorów Archiwum Narodowego w Sztokholmie Skoklostersamlingen, w którym wykazał poważne braki w mikrofilmach AGAD w stosunku do poloników ze Skokloster Riksarkivet oraz przedstawił wartościowe teksty do wydania, które

10 Efektem pracy zespołu pracującego nad archiwaliami i starodrukami ze Skokloster są pozycje: Skoklostersamlingen (seria: Polonika w zbiorach Archiwum Narodowego Szwecji, red. A. Nowicka-Jeżowa, red. A. Nowicka-Jeżowa, t. I), Warszawa 2006 (pozycja ta zawiera opis zbioru, bibliografię oraz jego zawartość); Sprawa Smoleńska. Z literatury okolicznościowej pierwszej połowy XVII wieku (seria: Polonika w zbiorach Archiwum Narodowego Szwecji, red. A. Nowicka-Jeżowa, t. II), wyd. M. Kacprzak, Warszawa 2006; Pamiątka rycerstwa sarmackiego i senatorów Obojga Narodów przy żałosnej śmierci Jana Karola Chodkiewicza, (seria: Polonika w zbiorach Archiwum Narodowego Szwecji, red. A. Nowicka-Jeżowa, t. III), wyd. D. Chemperek, Warszawa 2006; $\mathrm{S}$. Niemojewski, Diariusz drogi spisanej i różnych przypadków pociesznych i żałosnych prowadzac córkę Jerzego Mniszka, Marynę Dymitrowi Iwanowiczowi w roku 1606 (seria: Polonika w zbiorach Archiwum Narodowego Szwecji, red. A. Nowicka-Jeżowa, t. IV), wyd. R. Krzywy, Warszawa 2006.

11 R. Krzywy, „Reges et principes Regni Poloniae” Adriana Kochana Wolskiego jako przykład wierszowanego katalogu władców, „Acta Sueco-Polonica”, 10/11 (2001-2002), s. 95-119. 
w profesjonalny sposób opisuje wraz z tłem historycznym. Artykuł Extranea. Polen - charakterystyka zbioru autorstwa Jadwigi Wronicz nie przedstawia zasobu ze Skokloster, ale archiwalia przywiezione jako łup wojenny do Szwecji przez Karola Gustawa i Karola XII noszące nazwę Extranea. Tekst ten przybliża nam ogólnie zawartość tego zbioru, jednakże biorąc pod uwagę bardzo niekompletny inwentarz tego zbioru wydany w $1955 \mathrm{r}^{12}$, jest to opis bardzo interesujący i pomocny. Elżbieta Święcicka przedstawiła nam artykuł pt. Nauka, zabawa, dyplomacja $i$ wojna $w$ trójkącie szwedzko-polsko-tureckim. Na podstawie listów Zachariasza i Ewy Gamockich oraz Jana Herbiniusa. Tekst napisany ładną polszczyzną, w sposób profesjonalny z pełnym warsztatem historycznym. Jedynym mankamentem jest to, że nie zawsze Autorka prawidłowo podaje adresy stron internetowych, bez podania daty skorzystania (przyp. 16, s. 93). Ulla Ehrensvärd w tekście The Compile the Catalogue „Cartographica Poloniae 1570-1930” uzupełniła wydany w 2001 r. katalog dotyczący źródeł kartograficznych znajdujących się w archiwach szwedzkich i dotyczących terenów Estonii ${ }^{13}$. Tekst ten jest bardzo pożyteczny, tym bardziej że poszerza tematykę zawartą w tytule książki. Kolejny tekst Pożadane sposoby udostępniania poloników szwedzkich do badań nad historia języka polskiego autorstwa Włodzimierza Gruszczyńskiego, wybitnego językoznawcy, który przez wiele lat pracował jako lektor języka polskiego w Uppsali, dotyczy metodyki w udostępnianiu archiwaliów. Tekst ciekawy, wykraczający poza zagadnienia sugerowane w tytule recenzowanej pozycji. Joanna Okoniowa przedstawiła tekst Józef Trypućko (1910-1983), który przybliża nam sylwetkę profesora i wybitnego intelektualisty polskiego zamieszkałego w Szwecji. Elisabeth Löfstrand w swoim referacie The Novgorod Occupation Archives opisuje tzw. archiwum okupacyjne miasta Nowogrodu z lat 1611-1617, które zostało wywiezione po pokoju w Stołbowie (1617 r.) do Szwecji. Ostatni artykuł Ewy Berndtsson Rola Riksarkivet w przechowywaniu i udostępnianiu poloników zawiera krótki opis tego, co nazywamy polonikami w Riksarkivet, historię tego archiwum oraz zadania, organizację i przechowywanie oraz udostępnianie zasobów przez Riksarkivet. Tekst bardzo przydatny przede wszystkim ze względu na jego „techniczną” stronę pracy w archiwum.

Tematyka niektórych tekstów sprawia wrażenie pewnego chaosu, bowiem książka z założenia redakcji miała dotyczyć przede wszystkim materiałów ze zbioru Skoklostersamlingen. Polska brev och handlingar, tymczasem teksty: Jadwigi Wronicz (s. 81-87) Elżbiety Święcickiej (s. 89-103), Ulla Ehrensvärd (s. 105-122), Włodzimierza Gruszczyńskiego (s. 123-131), Elisabeth Löfstrand

\footnotetext{
12 Extranea: Polen (vol 75-145), opr. K. Maławski, Sztokholm 1955.

13 U. Ehrensvärd, Topographica Estoniae. Handritade kartor och ritningar över Estland $i$ svenska offentliga samlingar, „Annales Societatis litterarum Estonicae in Svecia”, t. 12 (1991-1999), Stockholm 2001, s. 2-289.
} 
(s. 141-149), Ewy Berndtsson (s. 150-163) poruszają zagadnienia nie zawsze przystające do tytułu publikacji. Jednakże pomimo tego, w moim przekonaniu zabieg ten sprawia, że recenzowana pozycja zyskuje, bowiem poruszane są w niej tematy poloników znajdujących się w Szwecji. W pozycji tej znajduje się również tekst, nie korespondujący bezpośrednio ze zbiorami z zamku Skokloster, Joanny Okoniowej, a dotyczący postaci prof. Józefa Trypućki. Artykuł ten umieszczony został w recenzowanej pozycji ze względu na wyżej wspomnianego patrona konferencji. Omawia on nie tylko losy wybitnego profesora, lecz również jego wkład w naukę oraz poświęcenie polskim archiwaliom i ich upowszechnieniu.

Pozycja zawiera również aneks w formie artykułu E. Berndtsson, który w rzeczywistości nie pełni funkcji aneksu, a jest zwykłym artykułem. Na końcu pracy znajduje się cenny wykaz opublikowanych tekstów w ramach polsko-szwedzkiego projektu poświęconego omawianemu zbiorowi poloników w Riksarkivet oraz ilustracje wybranych grafik, rękopisów oraz zdjęć niektórych obiektów szwedzkich związanych $\mathrm{z}$ archiwaliami.

Książka powstała w kręgu badaczy językoznawców. Jednakże tematyka przedstawionych $\mathrm{w}$ niej tekstów z pewnością dotyczy nie tylko polonistów, ale również jest przydatna dla historyków czy archiwistów.

Recenzowana książka pozytywnie wpisuje się w tematykę badań nad zasobami archiwalnymi polskich materiałów znajdujących się poza granicami Polski. Zbiory w Szwecji dzięki naukowemu opracowaniu są i będą coraz częściej wykorzystywane przez polskich uczonych, co jest chyba największym sukcesem. Polonica in the Swedish National Archives. The Skokloster Collection and Other Materials jest pozycją cenną i w moim przekonaniu wpisze się na stałe do polskiej literatury naukowej, często wykorzystywanej.

Wojciech Walczak Białystok 